\title{
The Public Perception of Public Transportation in Malaysia
}

\author{
*Teddy Pelangi Santuri ${ }^{1}$ and Nur Atiqah Binti Baharom ${ }^{2}$ \\ ${ }^{1)}$ Graduate Student of Geography Education, Universitas Negeri Padang, Indonesia \\ e-mail: teddy.senturi@gmail.com \\ 2) Student of Geography, Malaya University, Malaysia \\ e-mail: ciktiqh16@gmail.com
}

*Corresponding Author, Received: September 14, 2018, Revised: October 21, 2018, Accepted: December 05, 2018

This is an open acces article distributed under the Creative Commons 4.0 Attribution License, wich permits unrestricted use, Distribution and reproduction in any medium provided the original work is properly cited @2017 by author and Universitas Negeri Padang

\begin{abstract}
The purpose of this study was to analyze public perceptions of public transportation in Malaysia. The type of research used is qualitative research. Data collection techniques are by observation, interview, and documentation, which then obtained data are analyzed using qualitative analysis. The results showed that people used various types of public transportation in Malaysia according to their daily needs. To avoid congestion, many people use trains, other than that people also often use buses, also now since the emergence of online transportation such as Grab, many people have also switched to using Grab, besides that, Taxis are usually used by people every day.
\end{abstract}

Keywords: Transportation, Public Perception, Malaysia

\section{Introduction}

In this modern era transportation has become a special need that must be owned by every person or families. Become a basic need for urban society (Hermon, 2016; Hermon, 2017). The function of transportation in urban activities has an important role that influences in all aspects of life. In addition to private vehicles, a public transportation is also needed as a means of supporting the transportation of daily activities to meet needs. Transportation in this life has become a fundamental need that is very important especially for urban communities. The function of transportation in activities in urban areas has an important role that influences in all aspects or sectors of life. Communities in general need public transportation in addition to private vehicles as a support for their daily activities to meet their needs (Hermon, 2010; Hermon, 2012; Hermon, 2015; Rio, 2015). Transportation is a very influential element in economic stains. All aspects of the nation's life depend on this one sector, which functions as a driving force, supporter and driver of economic growth. That is, if this transportation sector is not well developed, it can be ascertained that development and even distribution of development and its results cannot be optimally utilized for all people (Sigit, 2010). Malaysia is a developing country in Asia with a population of 32 million (Position of Malaysian Statistics 2017). As a developing country Malaysia must prioritize development for the betterment of its people. In a development it is very closely related to transportation. The success of development is strongly influenced by the role of transportation as the lifeblood of political, economic, socio-cultural and defense security. The transportation network system can be seen in terms of effectiveness, in the sense of being safe, high accessibility, integrated, sufficient capacity, orderly, smooth and fast, easy to achieve, timely, convenient, affordable, orderly, safe, low pollution and in terms of efficiency low public burden and high utility in a single network transportation system (Hermon, 2009). Transportation is defined as an act of process or a matter of transportation or something that is transported, and with the verb to transport means "to 
move from one place to another". In other words, transportation means a process of movement or movement of people and / or goods from one place to another by using a particular system for a specific purpose or purpose. Human activities in fulfilling their needs cause them to need to be ruffled and interconnected in this case transportation becomes an integral part of a society function which shows a very close relationship with lifestyle, reach and location of productive activities, goods and services available for consumed (Molok, 2011) in Christian (2013).

The purpose of the existence of passenger public transport is to provide good and decent transportation services for the community. Good service size is a safe, comfortable, inexpensive, and fast service. Besides that, the presence of public transport passengers opens jobs. So, in determining the choice of type of transportation, people consider various factors, such as the purpose of the trip, distance and travel time, cost and level of comfort, and safety (Tamin, 2000) in (Christian, 2013). Transportation can promote economic and community welfare, create and increase the level of accessibility of natural resource potentials and market area, especially for public transportation. Public transportation or public transportation is a service facility that serves urban community mobilization services to support various activities undertaken. Public transportation that is good, smooth, clean, comfortable and safe reflects a good and healthy city condition. On the contrary, public transportation that is not feasible reflects the condition of a city that is not suitable to be inhabited. (Rayindra and Martinus, 2014; Hermon et al., 2018)

Based on research conducted by FT Confidential Research, Malaysia gets the best value in public transportation services. A study of transportation geography generally focuses on "transportation networks, locations, structures, currents, and the significance and influence of networks on economic space related to the development of regions with the principle of dependence between networks and economic space as well as changes in accessibility". In this case the better the transportation network, the better the accessibility so that economic activities are also growing (Hurst, 1974 in Adisasmita, 2011).

\section{Method}

The type of research used is qualitative (Hermon et al., 2008), which aims to find out people's perceptions of public transportation in Malaysia. Technical data collection used in this study is by observation which aims to obtain data directly to the field, data is also obtained by conducting interviews that aim to obtain information and desired information related to public perception of public transportation in Malaysia, in addition to technical data collection used in this study also with documentation that aims to strengthen and support the data obtained related to research. Data Analysis Techniques used are qualitative analysis. All data collected in the field were analyzed carefully and intensively related to people's perception of public transportation in Malaysia.

\section{Results and Discussion}

Morlok (1978) in Christian (2013) defines transportation as "an action, process, or thing that is moved from one place to another". More specifically, transportation is defined as "the activity of moving people and goods from one place to another". In transportation there is an element of movement (movement), and physically there is a movement of people or goods with or without transportation to another place. Cole (2005) in (Edy et al., 2018) argues that transportation is a service that is unusual in demand and has its own characteristics. Demand for transportation is said to be a derived demand which means that demand will occur because there are factors that drive it. There are several factors in determining the demand for transportation, including, physical characteristics, price, passenger income, service speed, quality of service, comfort, accuracy, and security.

Transportation is a very influential element in the economy. All aspects of the nation's life depend on this one sector, which functions as a driving force, supporter and driver of economic growth. This means that if the transportation sector is not well developed, it can be ascertained that development and even distribution of development and its results cannot be optimally utilized for all people. Understanding Transportation proposed by Nasution (1996) is defined as the transfer of goods and people from the place of origin to the destination. So that with these activities there are three things, namely the cargo being 
transported, the availability of vehicles as a means of transport, and the presence of roads that can be traversed. The process of moving from the movement of the place of origin, where the transport activity begins and to the destination where the activity is terminated.

Another definition was stated by Soesilo (1999) who argued that transportation is a movement of people's behavior in space both in carrying themselves and carrying goods. The arrangement of the transportation system must be carried out in an integrated manner as a unity of the national transportation system in order to be able to realize the availability of transportation services for transportation services that are balanced with the level of needs / demand, which are feasible at low cost so that they can be affordable by all people (Sigit, 2010).

Transportation as the lifeblood of population mobilization in the city becomes a top priority in improving the existence of transportation facilities and infrastructure in Malaysia. Transportation is not just moving an object from one point to another, but as the main element of the formation of a city with a population of 32 million people with a variety of personal interests. Public transportation is a service facility that serves urban community mobilization services to support various activities undertaken. Public transportation that is good, smooth, clean, comfortable and safe reflects a good and healthy city condition. Conversely, public transportation that is not feasible reflects the condition of a city that is not feasible to live in (Rayindra and Martinus, 2014)

Transportation in a country is very useful to provide easier access to the community to carry out daily activities. Until now Malaysia as a country with a modern transportation system is able to provide more equitable access to all regions. One of the most common and often chosen means of transportation to meet public access in Malaysia is the bus. Other types that are often used today are Taxi and Grab. The use of Grab is considered more practical because of its direct access between addresses compared to using other transportation such as buses.

As a means of public transportation, transportation must meet the criteria for public services. (Dagun, 2006) reveals that good transportation for public services must meet three basic criteria, namely comfort, security, and speed. The first provision is convenience, namely the comfort aspect must be felt by passengers who use transportation services. Passengers will feel comfortable in the means of transportation if the facility is equipped with various facilities that provide comfort for the occupants, one of which is air conditioning, impermeable to motor vehicle fumes, and the process carried out by prospective passengers before and after being in the means of transportation.

The second provision is security, namely the aspect of security felt by passengers during getting transportation services. Some of the indicators used in measuring security include a closed system where transportation is not easily accessible to other parties who are not passengers. In the case of buses, including bus stops or terminals that are only accessed by passengers who have purchased bus tickets. Besides that, it is a system of up and down passengers. In order to maintain the security of passengers, they must go up and down only at designated bus stops and terminals, and passengers cannot go up and down at b and bus stops other than the official terminal. Thus, this closed system can provide a sense of security for passengers from the threat of theft, pickpocketing, robbery, or other incidents that threaten the safety of passengers in using transportation services.

The third provision is speed, namely the provision of fulfilling time to the destination quickly and accurately. This provision can only be fulfilled if the means of transportation are supported by special facilities. An example is a special rail owned by a train. So that by adopting railway infrastructure, bus transportation can also be implemented by building a special lane or called Busway. The transportation system is a unit of physical facilities, flows and a control system that allows people and goods to move from one place to another efficiently in order to fulfill needs. In urban planning (urban planning), the availability of good public transportation is part of urban development. This concept has been carried out by many developing cities.

Kuala Lumpur as the capital of Malaysia became one of the metropolitan cities which was followed by significant developments in population migration both domestic and international. Congestion problems are also experienced by this city. To overcome congestion and improve public services, Kuala Lumpur has organized integrated urban public transportation. Transportation in Kuala Lumpur shows remarkable progress 
using good interconnections. Malaysia has succeeded in becoming the best public transport infrastructure country in ASEAN. Thus the results of research from FT Confidential Research, an institution that is under the International Financial Times. Broadly speaking there are two types of public transportation in Kuala Lumpur: rail and bus transportation. Rail transportation is divided into 4 types: KL Monorail, LRT (Light Rapid Transit), KTM Komuter, and KLIA Express / KLIA Transit.

Monorail or monorail is a rail-based mode (not a system) that only has one rail line as a support. KL Monorail only has 2 carriages with a line in the city center. Tickets can be purchased at the vending machine. The user is by choosing the destination station, then the nominal amount that must be paid is displayed. After the money is entered, the machine will issue a change (if any) and a ticket in the form of a coin. Tap coins on entry gate to enter. Enter the exit gate slot if it reaches the destination. The Monorail KL has been integrated with the LRT, so there is no need to buy a ticket again if you want to change lanes. LRT is a system. The Kuala Lumpur LRT Train has a series of carriages running on the railroad tracks. However, the LRT track does not cross the middle of the road but drifts in the elevated rail. There are three paths for LRT, namely Ampang, Sri Petaling, and Kelana Jaya passes. LRT connects the city center of Kuala Lumpur with areas in the metropolitan area. KTM (Kereta Tanah Melayu) Commuter is a short distance train that is not integrated with LRT and Monorail. Tickets can be purchased from the vending machine or the ticket counter at the station. Meanwhile KLIA Express and KLIA Transit are more dedicated as means of transportation to and from the airport, both KLIA and KLIA2 Airport. Trains and trajectories are the same, only KLIA Transit has three stop stations in Bandar Tasik Selatan, Putra Jaya, and Salak Tinggi. KTM has free Wifi facilities that add to the convenience of users. Tickets can be purchased from the counter. There are many buses in Kuala Lumpur ranging from inner city buses, hop on hop offs, airport buses, inter-city buses, to intercity buses. Buses to get around the famous city in Kuala Lumpur are the RapidKL and Go-KL buses. RapidKL buses are in great demand by the public because there are quite a lot of routes and fleets and timely departures. Payments are made on the bus by putting money in the small boxes next to the driver. While the Go-KL bus is free of charge, so there are many bus enthusiasts. Not only among tourists, but also the community. In addition there is also a simpler city bus, named Metrobus. Public perception about bus-like public transportation in Malaysia is the right alternative for traveling and traveling around Malaysia because of the relatively cheap ticket prices and orderly and safe bus services that make public transportation much in demand by Malaysians and immigrants from outside Malaysia.

Public perception about more modern and efficient public transportation such as KL Monorail, Star LRT, ERL, and KTM Komuter. This type of transportation is much more widely used by Malaysians and people from other countries because this type of transportation has its own lines and stations, free from congestion, and on time in each area that has a station. This type of transportation is in demand by various groups of people, old, young and children. Services in this transportation prioritize parents and pregnant women to sit in a chair, then the price of transportation tickets is adjusted to the distance per station. In addition, people also use other public transportation such as taxis. Public perception about taxi transportation, transportation of a kind of taxi is also often used by people in Malaysia because of its free and unlimited lane, transportation of a kind of taxi can directly take passengers to the address to be addressed, In addition, public transportation that is no less popular with Malaysians at this time is the emergence of Grab, Grab is one of the most popular transportation for the public because it can be picked up and delivered directly to the address, compared to taxis since the appearance of Grab in Malaysia Grab transportation This is quite desirable because if using a taxi, consumers must wait in advance to find a temporary taxi using Grab, just click on an application Grab consumers can be picked up immediately where the point is at that time and delivered according to the address to be addressed. The development of digital-based businesses provides convenience to the community, one of which is in meeting transportation or public transportation needs. Grab is one of the prima donnas for the community to travel long distances and short distances. Not only that, transportation can also improve tourism development in Malaysia (Umar, 2017), the criteria that will be used to increase tourism potential are public acceptance, availability of tourism facilities and government support, so that transportation is one of the supporting means of development tourism in Malaysia. In accordance with the arrangement of the transportation system must be carried out in an integrated manner as a unity of the national transportation system in order to be able to realize the availability of transportation services that are balanced with the level of demand / demand, which is feasible at low cost so that it can be affordable by all people (Sigit, 2010) then public transportation in Malaysia at this time it was said to be quite good, the public 
could choose the transportation that would be used in accordance with the needs / specialization to support the daily activities of the community.

\section{Conclusion}

Public transportation in Malaysia at this time has been said to be quite good, the public can choose the transportation that will be used in accordance with the needs / specialization to support the daily activities of the community both rail-based transportation and other transportation such as buses, taxis, and Grab have provided convenience to Malaysians to carry out daily activities. All types of transportation have provided comfort for the community, and also become easy and cheap as a magnet for passengers in using public transportation. By using public transportation, it has reduced the use of private transportation that causes traffic jams. The community uses public transportation according to their daily needs, to avoid congestion, many people use rail-based transportation, for relatively cheap costs, people use buses, and for speed and accuracy to reach the destination of the community using Taxi and Grab.

\section{References}

Adisasmita, S. A. 2011. Transportasi dan Pengembangan Wilayah. Yogyakarta: Graha Ilmu.

Bagus, R. 2015. Kualitas Pelayanan Transportasi Publik (Studi Deskriptif tentang Kualitas Pelayanan Jasa Angkutan Umum Perum Damri Unit Angkutan Bus Khusus Gresik-Bandara Juanda). Jurnal Kebijakan dan Manajemen Publik Vol 3 No. 2 Mei-Agustus 2015. Hal 1

Christian Y and J. A Timboeleng. 2013. Analisa Karakteristik Moda Transportasi Angkutan Umum Rute Manado Tomohon dengan Metode Analisa Biaya Operasional Kendaraan (BOK). Jurnal Sipil Statik Vol 1 No. 8 Juli 2013. Hal 2

Dagun, S. M. 2006. Busway, Terobosan Penanganan Transportasi Jakarta. Jakarta:Pustaka Sinar Hrapan. Hal 126

Haryono, S. 2010. Analisis Kualitas Pelayanan Angkutan Umum (Bus Kota) di Kota Yogyakarta. Jurnal Administrasi Bisnis, Vol 7 No 1 Juli 2010. Hal 1

Hermon, D., Khairani., Daswirman., S. Karim., Dasrizal., and Triyatno. 2008. Metode dan Teknik Penelitian Geografi Tanah: Aplikasi Instrumen dan Acuan Penelitian Geografi Fisik. Yayasan Jihadul Khair Center.

Hermon, D. 2009. Dinamika Permukiman dan Arahan Kebijakan Pengembangan Permukiman pada Kawasan Rawan Longsor di Kota Padang. Disertasi. IPB Bogor.

Hermon, D. 2010. Geografi Lingkungan: Perubahan Lingkungan Global. UNP Press.

Hermon, D. 2012. Mitigasi Bencana Hidrometeorlogi: Banjir, Longsor, Degradasi Lahan, Ekologi, Kekeringan, dan Puting Beliung. UNP Press. Padang.

Hermon, D. 2015. Geografi Bencana Alam. Jakarta: PT RajaGrafindo Persada.

Hermon, D. 2016. Mitigasi Perubahan Iklim. Rajawali Pers (Radjagrafindo).

Hermon, D. 2017. Climate Change Mitigation. Rajawali Pers (Radjagrafindo).

Hermon, Dedi., Suasti, Yurni., Ernawati., Afdhal., and Edial, Helfia. 2018. Geografi: Geografi untuk SMU. Jurusan Geografi Universitas Negeri Padang.

Jabatan Statistik Malaysia. 2017. Anggaran Penduduk Semasa, Malaysia, 2016-2017. Jabatan Perangkaan Malaysia. Kuala Lumpur.

Mathew B. Miles and A. Michael Huberman. 2009. Analisis Data Kualitatif (Buku Terjemahan). Jakarta. UI Press

Nasution H.M.N. 1996. Manajemen Transportasi. Penerbit Ghalia Indonesia.

Soesilo. Nining I. 1999. Ekonomi Perencanaan dan Manajemen Kota. Jakarta. Magister Perencanaan dan Kebijakan Publik Universitas Indonesia. 
Sumatra Journal of Disaster, Geography and Geography Education

ISSN: 2580-4030 (Print) 2580-1775 (Online)

Vol 2, No. 2, (pp. 135-140), December, 2018

http://sjdgge.ppj.unp.ac.id

Sugiyono. 2008. MetodePenelitianpendidikan (Pendekatankuantitatif, kualitatifdan R\&D). Bandung: Alfabeta.

Umar, I. 2017. Prioritas Pengembangan Objek Wisata Di Kota Padang, Provinsi Sumatera Barat. Vol 6. No.1 